\title{
A RELAÇÃO CIDADE-CAMPO EM MARX: O CAPITAL, A RENDA DA TERRA E O LUCRO
}

\section{THE CITY-COUNTRYSIDE RELATION IN MARX: THE CAPITAL, GROUND RENT AND PROFIT}

\section{Vitor Bartoletti Sartori ${ }^{1}$}

\section{RESUMO}

No presente artigo, a partir daquilo que o filósofo brasileiro José Chasin chamou de análise imanente, buscaremos explicitar o modo pelo qual Karl Marx trata da relação cidade-campo. Para tanto, passaremos, principalmente, embora não só, por O capital. A partir da análise das diferentes figuras do capital, e da aplicação da ciência no campo, analisaremos como que, no próprio capitalismo, temse as potencialidades que poderiam propiciar, em uma forma mais avançada de produção, a superação da oposição entre campo e cidade e entre renda da terra e lucro.

Palavras-chave: Marx, relação cidade-campo, O capital

\section{ABSTRACT}

In this article, from what Brazilian philosopher José Chasin called immanent analysis, we will seek to explain the way Karl Marx deals with the city-country relationship. To this end, we will mainly, though not only, pass through The Capital. From the analysis of the different figures of capital, and the application of science in the field, we will analyze how, in capitalism itself, we have the potentialities that could provide, in a more advanced form of production, the overcoming of the opposition between countryside and city and between ground rent and profit.

Key-words: Marx, City-countryside relation, The capital

\footnotetext{
1 Professor adjunto da Faculdade de Direito da UFMG ligado ao departamento de Direito do Trabalho e introdução ao Direito. Universidade Federal de Minas Gerais - UFMG - Brasil. ORCID: https://orcid.org/00000001-9570-9968 Lattes: http://lattes.cnpq.br/0871083138441617 E-mail: vitorbsartori@gmail.com
} 


\section{INTRODUÇÃO}

Henri Lefebvre, em seu $O$ pensamento marxista e a cidade (2001), procura fazer uma análise cuidadosa do tratamento marxiano sobre a cidade. A partir de sua análise, chega a conclusões que colocam a cidade como central na emergência das relações de sua época (a segunda metade do século XX). Também traz a cidade como central na possibilidade da superação daquela que acredita ser a figura principal do capitalismo de seu tempo, "capitalismo burocrático de consumo dirigido". (Cf. LEFEVBRE, 1969, 1991 b) Neste contexto, em que vem a tratar da especificidade da vida urbana, do cotidiano moderno e da crise que marca a Europa do pós Segunda Guerra, o autor vem a dizer, ao analisar a Ideologia alemã, que "aqui, o sujeito da história é incontestavelmente a cidade." (LEFEBVRE, 2001, p. 49) A afirmativa tem muita força e um apelo muito forte: remete à centralidade das questões urbanas na conformação da história e do cotidiano da vida moderna. Aqui, porém, não analisaremos com todo o cuidado a pertinência de tal afirmativa. Antes, passaremos pela exposição da grande influência do autor francês, Karl Marx. Isto se justifica porque, se é verdade que a cidade vem a adquirir certa centralidade no pensamento de Lefebvre, talvez o mesmo não se dê, ao menos não do mesmo modo ou com a mesma ênfase, com o pensamento do autor de $O$ capital: neste, o tratamento da relação cidade-campo aparece, na década de 1840 , subordinado à crítica à divisão do trabalho; já, depois disso, com a maturação dos estudos de Marx sobre a economia política depois da década de 1850, a temática atinente à cidade e ao campo vem a subordinar-se ao movimento das diferentes figuras econômicas que são imanentes ao sistema capitalista de produção (principalmente a renda e o lucro). Ou seja, por mais que o pensamento marxiano não veja a cidade como simples epifenômeno do econômico, o sujeito da história dificilmente pode ser considerado como a cidade, e muito menos de modo incontestável.

Obviamente há muitos meandros na análise lefebvriana. Eles são interessantíssimos. No entanto, pode-se dizer que a afirmativa do autor francês (acima citada) não corresponde à posição de Marx. Isto, claro, não é problema algum, desde que considere-se tal afirmação como uma inovação de Lefebvre, e não como uma leitura rigorosa da obra de Karl Marx. Assim, de modo mais ou menos mediado, desenvolveu-se uma importante tradição de análise marxista baseada em Lefebvre e na noção de direito à cidade. (Cf. LEFEBVRE, 1991 a) Nela, porém, não se deu - fora no caso do próprio Henri Lefebvre (2001) - a análise cuidadosa do pensamento do próprio Marx. 
Aqui, a partir daquilo que José Chasin chama de análise imanente ${ }^{2}$, pretendemos dar alguns passos neste caminho. Para tanto, analisaremos principalmente $O$ capital de Karl Marx.

Isto se dá porque a parte menos desenvolvida da pesquisa lefebvriana está na análise da crítica da economia política. O autor francês analisa principalmente $A$ ideologia alemã (cf. LEFEBVRE, 2001). Isto, claro, é bastante importante. Precisa passar por uma correlação entre a divisão do trabalho, central na obra de 1845, mas já trabalhada por Marx em 1844 nos Manuscritos econômico-filosóficos. E tal centralidade da divisão do trabalho e da análise da propriedade está presente nos apontamentos marxianos sobre a cidade de $A$ ideologia alemã, obra analisada por Lefebvre. No entanto, o autor francês acaba por trazer o destaque maior - até mesmo por uma estratégia de exposição - à cidade, inclusive como sujeito da história. Ou seja, mesmo que o autor de Direito à cidade nunca deixe de ter em conta elementos essenciais da economia política e da crítica da economia política, estes fatores vêm a ter um papel secundário em seus textos, sejam estes últimos sobre o próprio Marx, sejam eles mais propriamente autorais e ligados à crítica ao capitalismo vigente na época do autor. Assim, também por isso, vale a pena nos voltarmos à relação cidade-campo, no autor de $O$ capital, tendo em mente a ênfase do próprio pensador alemão na crítica da economia política. Sem, de modo algum, desvalorizar as conquistas de Lefebvre e daqueles que têm em sua obra uma grande referência, trataremos dos apontamentos de $O$ capital.

Uma razão mais óbvia, embora não menos importante para tal análise diz respeito à importância de Marx à conformação das ciências sociais. Nelas, seja por meio de uma negativa (não raro veemente), seja ao procurar seguir os passos do autor alemão, tem-se em Marx um clássico. Para aqueles que pretendem refutar Marx e o marxismo, nossa análise pode ser importante para que não se tenha a crítica a algo simplificado; no que diz respeito aos marxistas, procuraremos mostrar alguns meandros da obra marxiana que, até agora, não vieram à tona com o devido cuidado. ${ }^{3}$

\footnotetext{
${ }^{2}$ Como aponta José Chasin: "tal análise, no melhor da tradição reflexiva, encara o texto - a formação ideal - em sua consistência autosignificativa, aí compreendida toda a grade de vetores que o conformam, tanto positivos como negativos: o conjunto de suas afirmações, conexões e suficiências, como as eventuais lacunas e incongruências que o perfaçam. Configuração esta que em si é autônoma em relação aos modos pelos quais é encarada, de frente ou por vieses, iluminada ou obscurecida no movimento de produção do para-nós que é elaborado pelo investigador, já que, no extremo e por absurdo, mesmo se todo o observador fosse incapaz de entender o sentido das coisas e dos textos, os nexos ou significados destes não deixariam, por isso, de existir [...]". (CHASIN, 2009, p. 26)

${ }^{3}$ Basta pensar no modo pelo qual os camponeses e a questão agrária foram vistos, por vezes, de modo simultaneamente e polêmica no século XX. Cf. BARAN, 1960; DEUTSCHER, 2006.
} 


\title{
A OPOSIÇÃO CIDADE-CAMPO EM MEIO À CONSOLIDAÇÃO DO CAPITAL
}

Talvez o primeiro ponto a se destacar no que diz respeito à cidade é sua historicidade. Ao menos desde a Ideologia alemã, Marx aponta que a cidade, tal qual a política, nem sempre existiu conjuntamente com a sociabilidade humana. ${ }^{4}$ Ela teria surgido somente depois de algum grau de desenvolvimento da atividade humana, aquele em que surgem o Estado e as classes sociais:

\begin{abstract}
Com a cidade surge, ao mesmo tempo, a necessidade da administração, da polícia, dos impostos etc., em uma palavra, a necessidade da organização comunitária e, desse modo, da política em geral. Aqui se mostra, pela primeira vez, a divisão da população em duas grandes classes, que se baseiam diretamente na divisão do trabalho e nos instrumentos de produção. A cidade é, de pronto, o fato da concentração da população, dos instrumentos de produção, do capital, das fruições, das necessidades, enquanto o campo evidencia exatamente o fato contrário, a saber, o isolamento e a solidão. A oposição entre cidade e campo só pode existir no interior da propriedade privada. É a expressão mais crassa da subsunção do indivíduo à divisão do trabalho, a uma atividade determinada, a ele imposta - uma subsunção que transforma uns em limitados animais urbanos, outros em limitados animais rurais e que diariamente reproduz a oposição entre os interesses de ambos. O trabalho é, aqui, novamente o fundamental, o poder sobre os indivíduos, e enquanto existir esse poder tem de existir a propriedade privada. A superação da oposição entre cidade e campo é uma das primeiras condições da comunidade, uma condição que, por seu turno, depende de uma massa de pressupostos materiais e que não pode ser satisfeita pela mera vontade, como qualquer um pode constatar à primeira vista. (Tais condições têm ainda de ser desenvolvidas.) A separação entre cidade e campo também pode ser apreendida como a separação entre capital e propriedade da terra, como o início de uma existência e de um desenvolvimento do capital independentes da propriedade da terra, o início de uma propriedade que tem como base apenas o trabalho e a troca. (MARX; ENGELS, 2007, p. 52)
\end{abstract}

Na passagem, Marx aponta que a cidade traz consigo aquilo que pode ser caracterizado como a política. Ambas, portanto, não têm uma existência supra-histórica. Tal processo tem por base a emergência das classes sociais e da divisão do trabalho, esta última que se dá entre trabalho manual e intelectual e, em meio a isto, entre campo e cidade. $O$ autor de $O$ capital não deixa de apontar neste processo um grande avanço; mas ele é também marcado por contradições gritantes.

A cidade seria o locus do incremento das forças produtivas e da vida conjunta em oposição ao campo, em que imperaria a solidão e o isolamento. Porém, isto se daria às custas de o poder dos indivíduos existir principalmente sob a forma da propriedade privada e também ao se ter como característica de uma época a subsunção do indivíduo à divisão do trabalho. Assim, por mais que exista claramente avanços no que toca a vida urbana, esta não é "a" referência para Karl Marx. O autor diz

\footnotetext{
${ }^{4}$ Sobre a determinação ontonegativa da politicidade, Cf. CHASIN, 1999, 2009.
} 
que "as grandes rebeliões da Idade Média partiram todas do campo, mas foram totalmente malsucedidas devido à dispersão e à consequente rudeza dos camponeses." (MARX; ENGELS, 2007, p. 53-54) também aponta, em uma afirmativa com a qual não concordará mais ao ter em conta o desenvolvimento russo da década de 1880 (Cf. MAEX; ENGELS, 2013), que "se qualquer modo, um movimento comunista jamais poderá partir do campo, mas partirá sempre das cidades apenas." (MARX; ENGELS, 2007, p. 342) No entanto, o autor fala também de limitados animais urbanos e de limitados animais rurais; deixa claro que não tem por objetivo preservar o elemento urbano em oposição ao rural. Antes, acredita que seja necessário superar e suprimir a própria oposição entre a cidade e campo. Ou seja, mesmo que a cidade seja, tipicamente, o locus em que se desenvolvem as forças produtivas, não se pode simplesmente defender a vida urbana contra a rural.

Em Marx, trata-se da supressão da oposição entre ambas.

E, deve-se destacar que, para chegar a esta posição, em Marx, desde a década de 1840, há uma fundamentação colocada no estudo da economia política. Tanto é assim que o autor diz que à divisão cidade-campo corresponde a oposição entre capital e propriedade da terra. Ou seja, mesmo nos apontamentos mais gerais do autor de $O$ capital sobre a relação cidade-campo, o conhecimento sobre a economia política joga um importante papel. Se é verdade que os estudos sobre esta última temática ainda não continham, na década de 1840, a maturidade que viriam a adquirir no final da década de 1850, igualmente verdadeiro é que a oposição cidade-campo só pode ser compreendida, em Marx, ao se ter em conta a posição crítica do autor alemão sobre a economia política, e sobre as consequências desta e da visão de mundo dos seus defensores. Assim, caso se queira compreender a questão com o cuidado devido, faz-se necessária a análise da questão, também, em 0 capital.

Para que comecemos nossa análise, vale ver o que diz o autor na seguinte passagem:

Está na natureza da coisa que, assim que a indústria urbana enquanto tal se separa da agrícola, seus produtos são de antemão mercadorias e sua venda necessita, portanto, da mediação do comércio. Que o comércio se apoie no desenvolvimento urbano e que, por outro lado, este último esteja condicionado pelo comércio, é nessa medida evidente. No entanto, aqui depende por completo de outras circunstâncias até que ponto o desenvolvimento industrial anda lado a lado com aquele. (MARX,1986 b, p. 249)

Marx aponta na emergência da indústria urbana a oposição com a indústria agrícola e a necessidade da mediação do comércio. Assim, tem-se, no capitalismo, como determinação de reflexão o capital industrial, o capital comercial e a existência da renda da terra. E mais, para que se use a diç̧ão das Glossas sobre Wagner, o que se tem aqui não é, como quer Lefebvre (2001), a cidade como sujeito, mas a mercadoria: "nem 'o valor' nem 'o valor de troca' são para mim os sujeitos, mas sim a mercadoria." (MARX, 2017, p. 255) Há uma relação de interdeterminação entre o desenvolvimento 
urbano e o comercial, certamente. No entanto, o processo social de uma sociedade subsumida ao capital - Marx trata na passagem do modo de produção capitalista - a mediação mercantil vem a ser central, estando apoiada na própria relação-capital. ${ }^{5}$ Ou seja, aquilo de que depende o modo pelo qual se desenvolve a oposição entre a indústria urbana e agrícola não está na própria conformação da cidade primariamente. Antes, o momento preponderante desta relação está situado nas contradições da própria produção econômica capitalista; trata-se de diferentes "momentos de um processo no qual a produção é o ponto de partida efetivo, e, por isso, também o momento predominante [übergreifende Moment]." (MARX, 2011, p. 68) A relação entre a indústria urbana e rural, portanto, diz respeito à própria conformação - também espacial, pode-se dizer - da relação-capital. Para Marx, "a relaçãocapital pressupõe a separação entre os trabalhadores e a propriedade das condições de realização do trabalho. Tão logo a produção capitalista se apoie sob os próprios pés, não apenas conserva tal separação, mas a reproduz em escala sempre crescente." No que acrescenta o autor: "portanto, o processo que cria a relação-capital não pode ser outra coisa que não o processo de separação entre o trabalhador e a propriedade das suas condições de trabalho" e complementa, "um processo que por um lado transforma os meios sociais de subsistência e de produção em capital, por outro, os produtores imediatos em operários assalariados." (MARX, 1996 b, p. 340) Somente deste modo temse a mercadoria como essencial no sociometabolismo das relações econômicas ${ }^{6}$ e só assim o comércio ganha a força suficiente para que se tenha algo essencial à sociedade capitalista, a subordinação do campo à cidade.

Marx já dizia no Manifesto que "a burguesia submeteu o campo à cidade. Criou grandes centros urbanos; aumentou prodigiosamente a população das cidades em relação à dos campos e, com isso, arrancou grande parte da população do embrutecimento da vida rural." (MARX; ENGELS,1998, p. 131-132) Isto só foi possível com a centralidade da mediação mercantil; para que se use a dicção das Glossas sobre Wagner, ao passo que, neste processo, o sujeito é a mercadoria. Novamente, destacamos: o elogio marxiano do domínio da cidade sobre o campo não se confunde

\footnotetext{
${ }^{5} \mathrm{Em}$ a Ideologia alemã, Marx traz algo similar, embora não entre nas nuances da contradição entre o desenvolvimento das forças produtivas e das relações de produção: "a divisão do trabalho no interior de uma nação leva, inicialmente, à separação entre o trabalho industrial e comercial, de um lado, e o trabalho agrícola, de outro, e, com isso, à separação da cidade e do campo e à oposição entre os interesses de ambos. Seu desenvolvimento posterior leva à separação entre trabalho comercial e [trabalho] industrial. Ao mesmo tempo, por meio da divisão do trabalho no interior desses diferentes ramos, desenvolvem-se diferentes subdivisões entre os indivíduos que cooperam em determinados trabalhos. A posição dessas diferentes subdivisões umas em relação às outras é condicionada pelo modo como são exercidos os trabalhos agrícola, industrial e comercial (patriarcalismo, escravidão, estamentos, classes). As mesmas condições mostram-se no desenvolvimento do intercâmbio entre as diferentes nações." (MARX; ENGELS, 2007, p. 89)

${ }^{6}$ Somente assim, tem-se que "a riqueza das sociedades em que domina o modo de produção capitalista aparece como uma 'imensa coleção de mercadorias' e a mercadoria individual como sua forma elementar." (MARX, 1996 a, p. 165)
} 
com a tomada da cidade e da vida urbana como resolutiva. Para o autor, sempre, trata-se da supressão da oposição entre vida rural e urbana, de modo que está correto Raymond Williams ao dizer que "nem a cidade irá salvar o campo, nem o campo a cidade." (WILLIAMS, 2011, p. 490)

A posição de Marx sobre o embrutecimento da vida rural também está longe de ser unilateral. Por mais que o autor sempre tenha se colocado contra o isolamento do pequeno proprietário do campo, ele chegou a tratar de formas coletivas de organização econômica na comuna agrária russa, a qual, no limite, poderia servir de elo intermediário para o desenvolvimento do socialismo na Rússia. (Cf. MARX; ENGELS, 2013) Trataremos do assunto mais à frente; aqui, basta que mencionemos que o domínio da cidade sobre o campo nada tem de idílico.

Ele remete, ao processo da acumulação originária (ou primitiva), tratado por Marx no famoso capítulo XXIV de $O$ capital, em que se tem a expropriação das terras dos camponeses e:

O roubo dos bens da Igreja, a fraudulenta alienação dos domínios do Estado, o furto da propriedade comunal, a transformação usurpadora e executada com terrorismo inescrupuloso da propriedade feudal e clânica em propriedade privada moderna, foram outros tantos métodos idílicos da acumulação primitiva. Eles conquistaram o campo para a agricultura capitalista, incorporaram a base fundiária ao capital e criaram para a indústria urbana a oferta necessária de um proletariado livre como os pássaros. (MARX, 1996 b. p. 335)

Este processo é aquele segundo o qual a base fundiária é incorporada ao domínio do capital, na medida em que tem-se a conformação do proletariado livre. Neste cenário, vem a ser central a compra e venda da força de trabalho e, portanto, o assalariamento. Podemos dizer, assim, que a oposição entre cidade e campo, na sociedade capitalista, tem por base a relação-capital e o assalariamento. A conformação da propriedade privada moderna passa pelo roubo, pela violência, por leis sanguinárias, certamente. $\mathrm{E}$ isto se dá tendo como pano de fundo o estabelecimento e a consolidação das relações de produção capitalistas. Pode-se concordar com Raymond Williams novamente quando ele diz que "o capitalismo, enquanto modo de produção, é o processo básico por trás da maior parte da história do campo e da cidade que conhecemos." (WILLIAMS, 2011, p. 491) Lefebvre, em sua análise da obra de Marx, e ao trazer a cidade como "o" sujeito da história, assim, talvez inverta tal relação. Para Marx, o campo só é explorado pela cidade porque há um importante processo econômico subjacente a isto, e este processo é central. Diz-se livro III de $O$ capital:

Se, na Idade Média, o campo explorava politicamente a cidade onde quer que o feudalismo não tivesse sido superado por algum excepcional desenvolvimento urbano, como na Itália, assim também a cidade explorava o campo, em todo lugar e sem exceção, economicamente por meio de seus preços de monopólio, 
de seu sistema de impostos, de suas corporações, de seu engodo comercial direto e de sua usura. (MARX, 1986 b, p. 257-258)

O processo de consolidação da relação-capital tem por essencial tanto a violência da acumulação originária quanto a maneira pela qual formas antediluvianas de capital, como o capital comercial e o capital portador de juros preparam o terreno para o domínio do capital industrial. (Cf. MARX, 1986 a, b) Na idade média, o campo domina politicamente a cidade; na moderna sociedade capitalista, tem-se a cidade dominando, principalmente por meio da economia, o campo.

Há, assim, uma mudança substantiva, e que tem como elo intermediário o excepcional desenvolvimento urbano. A partir dele, com os preços de monopólio, com os impostos e corporações, com o lucro comercial e com o capital portador de juros, tem-se figuras que funcionam como formas de transição de um modo de produção a outro, no caso do feudal ao capitalista. Percebe-se, assim, que a proeminência do papel da cidade, em Marx, não se liga tanto à possibilidade da transição do capitalismo ao socialismo, mas de uma sociedade feudal a uma capitalista. A questão é de bastante relevo para o nosso tema: para Marx, o desenvolvimento propriamente urbano é indissolúvel deste processo, e não há como separá-lo da oposição entre cidade e campo (como acontece, por até certo ponto, em Lefebvre ${ }^{7}$ ). Percebe-se, assim, que a cidade passa a dominar o campo quando as categorias econômicas de transição começam a se impor tendo como solo o longo desenvolvimento das condições para a implementação da relação-capital.

A cidade e o urbano, portanto, jogam um papel ativo. Mas isto se dá ao se ter a própria conformação da relação-capital como algo que se coloca sobre os próprios pés. Não se trata de se ter o urbano como sujeito ou como ponto de partida para a luta anticapitalista, portanto. Mesmo que a vida cotidiana passe pelas relações mercantis, que prevalecem de modo mais acentuado na cidade, Marx nunca realiza uma espécie de hipostasia quanto à relação cidade-campo; o ponto de partida efetivo para a compreensão da propriedade capitalista está na conformação da própria produção. Se esta passa obrigatoriamente pela relação cidade-campo, não é verdade que esta última relação seja o momento preponderante da conformação objetiva da sociabilidade capitalista, e muito menos para a crítica desta. É verdade, porém, que somente com a vigência da produção da grande indústria o sistema capitalista de produção efetivamente se colocará sobre os próprios pés. É igualmente verdadeiro que na produção manufatureira que aparece nas cidades, e que tem o comércio e a oposição com a indústria agrícola como condição, é a pré-condição para a produção em que a relaçãocapital se assenta de modo mais típico, aquela da grande indústria. E, assim, são vários os meandros a se analisar ao se ter em mente a oposição cidade-campo em Marx.

\footnotetext{
${ }^{7}$ Isto se dá devido à diferenciação entre a cidade e o urbano, que ultrapassaria a cidade.
} 


\section{O CAMPO, A PROPRIEDADE PRIVADA, A GRANDE INDÚSTRIA, A GRANDE PROPRIEDADE AGRÁRIA E O DESENVOLVIMENTO CAPITALISTA}

O papel que Marx atribui à dominação da cidade sobre o campo, assim, não é pequeno. No entanto, neste processo, o sujeito não é propriamente a cidade, mas a mercadoria, ou para que se coloque de outro modo, tem-se a conformação de uma espécie de sujeito automático:

Na circulação $D-M-D,[. .$.$] , ambos, mercadoria e dinheiro, funcionam apenas$ como modos diferentes de existência do próprio valor, o dinheiro o seu modo geral, a mercadoria o seu modo particular, por assim dizer apenas camuflado, de existência. Ele passa continuamente de uma forma para outra, sem perder-se nesse movimento, e assim se transforma num sujeito automático. (MARX, 1996 a, p. 273-274)

Tal é o movimento que está subjacente ao papel que a cidade vem a adquirir na transição do feudalismo ao capitalismo. É verdade, porém, que isto pressupõe uma conformação toda específica do campo. Assim, no seio da tradição marxista, e em oposição a teorias clássicas sobre a Revolução Francesa e sobre a revolução burguesa em geral, como as de Georges Lefebvre (1989), surgem autores, como Dobb (1983) e Wood (2001), que enfocam a dinâmica das relações do campo na emergência do capitalismo. Ao passo que Georges Lefebvre enfatiza o papel da vida urbana e do comércio no surgimento do capitalismo e das condições para a Revolução Francesa, autores como Dobb dão destaque ao elemento endógeno ao desenvolvimento das relações de produção no campo como o elo essencial para o modo de produção capitalista. Wood, nesta esteira, também enfatiza certa origem agrária do capitalismo. Não poderemos entrar aqui nesta disputa da historiografia. No entanto, podemos destacar que no autor que aqui tratamos, Karl Marx, tem-se tanto um papel atribuído ao desenvolvimento da vida urbana e do comércio quanto à privatização da propriedade do campo. Ou seja, ambos processos são subjacentes e, de modo algum, seria possível separá-los. ${ }^{8}$ Assim, Marx traz à tona a importância do avanço do capital comercial, do capital portador de juros, e mesmo do capital organizado nas ações ${ }^{9}$, para a emergência do modo de produção capitalista. Mas também tem por essencial a apropriação privada da terra para a formação do capital:

\footnotetext{
${ }^{8}$ Aqui, cabe destacar que os autores mencionados não separam tais elementos, apenas dão ênfase bastante diferente a cada um destes momentos da consolidação da relação-capital.

${ }^{9}$ Sobre as sociedades por ações, na emergência do capitalismo, aponta: "o mínimo da soma de valor que deve dispor um possuidor individual de dinheiro ou de mercadorias para metamorfosear-se em capitalista varia em diferentes graus de desenvolvimento da produção capitalista e, dado o grau de desenvolvimento, é diferente nas diferentes esferas de produção, conforme as condições técnicas específicas de cada uma. Certas esferas de produção exigem já nas primeiras etapas da produção capitalista um mínimo de capital que ainda não se encontra em mãos de indivíduos isolados. Isso leva, em parte, o Estado a subsidiar tais particulares, como na
} 
Antes de mais nada, se a terra estivesse à livre disposição de todo mundo de maneira imediata, faltaria um elemento primordial para se formar o capital Uma condição de produção da maior essencialidade e excluído o homem e seu próprio trabalho - a única condição original de produção não poderia ser alienada nem ser objeto de apropriação e assim não poderia contrapor-se ao trabalhador como propriedade alheia e fazer dele trabalhador assalariado. A produtividade do trabalho no sentido ricardiano, isto é, capitalista, a "produção" de trabalho alheio não pago seria por conseguinte impossível. Com isso, a produção capitalista em geral teria um fim. (MARX, 1980, p. 476-477)

A existência da relação-capital pressupõe a apropriação privada da terra. A separação entre as condições de trabalho dos homens e eles mesmos, ou seja, entre os meios de produção e os trabalhadores é o que conforma a existência mais basilar do capital. $O$ trabalhador assalariado só surge ao passo que a apropriação da riqueza aparece na figura da propriedade estranha diante de significativa parcela dos indivíduos produtores. Ou seja, a conformação da propriedade privada capitalista certamente passa pela mediação do capital comercial e dos grandes centros urbanos. Mas tem por essencial a conformação da moderna propriedade privada; esta, em sua forma clássica, surge das relações que se dão no campo, ao se ter em conta a propriedade da terra. Sem esta forma de propriedade, não se poderia falar de produção capitalista ou mesmo de trabalho produtivo. ${ }^{10}$ Ou seja, se formos ser justos com o que diz o autor de $O$ capital, há colocações importantes sobre a cidade, certamente. Mas há também uma inter-relação bastante imbrincada entre cidade e campo em meio ao desenvolvimento capitalista. O central na análise marxiana sempre é este desenvolvimento.

A oposição entre trabalho isolado e trabalho social - este último que tende a se colocar já no próprio modo de produção capitalista - vem a ser importante no que toca o assunto:

A pequena propriedade pressupõe que a de longe preponderante maioria da população é rural e que predomina não o trabalho social, mas o trabalho isolado; que, por isso, a riqueza e o desenvolvimento da reprodução, tanto em suas condições materiais quanto espirituais, está excluído sob tais circunstâncias e, por conseguinte, também as condições de um cultivo racional. Por outro lado, a grande propriedade rural reduz a população agrícola a um mínimo em decréscimo constante e lhe contrapõe uma população industrial em constante

França no tempo de Colbert e em alguns Estados alemães até a nossa época, em parte à constituição de sociedades com monopólio legal para explorar determinados ramos industriais e comerciais - as precursoras das modernas sociedades por ações." (MARX, 1996 a, p. 423)

${ }^{10}$ Sobre a questão do trabalho produtivo, Cf. COTRIM, 2013. Veja-se Marx sobre a questão: "trabalho produtivo no sentido da produção capitalista é o trabalho assalariado que, na troca pela parte variável do capital (a parte do capital despendida em salário), além de reproduzir essa parte do capital (ou o valor da própria força de trabalho), ainda produz mais-valia para o capitalista. Só por esse meio, mercadoria ou dinheiro se converte em capital, se produz como capital. Só é produtivo o trabalho assalariado que produz capital. (Isso equivale a dizer que o trabalho assalariado reproduz, aumentada, a soma de valor nele empregada ou que restitui mais trabalho do que recebe na forma de salário. Por conseguinte, só é produtiva a força de trabalho que produz valor maior que o próprio."(MARX, 1980, p. 132) 
crescimento, amontoada em grandes cidades; gera, com isso, condições que provocam uma insanável ruptura no contexto do metabolismo social, prescrito pelas leis naturais da vida, em decorrência da qual se desperdiça a força da terra e esse desperdício é levado pelo contrário muito além das fronteiras do próprio país. (MARX, 1986 b, p. 266)

Marx trada das condições com as quais a pequena propriedade prevalece. Trata-se do predomínio da população rural e do trabalho isolado; ou seja, com a prevalência do parcelamento da propriedade, e com a pequena produção, não se tem dois fatores importantes para a compreensão da sociabilidade propriamente moderna: primeiramente, o afastamento das barreiras naturais (Cf. LUKÁCS, 2013) e, depois, a implementação da ciência como uma força produtiva (Cf. MARX, 2011). Estas duas só se colocam em meio ao desenvolvimento pleno do modo de produção capitalista. E, assim, conclui-se: a pequena propriedade como forma preponderante de apropriação da produção social não é típica do incremento das forças produtivas do trabalho. Portanto, não pode ser tomada como referência ao se ter em mente a superação do modo de produção capitalista.

A pequena propriedade também é antagônica à implementação daquilo que Marx chama de cultivo racional; no entanto, muito embora este seja trazido enquanto possibilidade em meio ao próprio desenvolvimento capitalista, ele nunca é efetivo no sistema capitalista de produção:

A moral da história, que se pode deduzir também de outras observações sobre a agricultura, é que o sistema capitalista se opõe a uma agricultura racional ou que a agricultura racional é incompatível com o sistema capitalista embora este fomente seu desenvolvimento técnico! e precisa da mão do pequeno camponês que trabalha pessoalmente ou do controle dos produtores associados. (MARX,1986 a, p. 92)

O incremento das forças produtivas torna possível a agricultura e a cultura racionais. Mas estas, segundo Marx, são incompatíveis com o modo de produção capitalista. Antes, para uma produção racional, seria preciso a superação do sistema capitalista, superação esta em que se tem os produtores associados. A produção racional, assim, somente seria possível em pequena escala com a produção pessoal do camponês - e, em condições de um domínio ainda pessoal e artesanal do processo - ou, em grande escala, com o desenvolvimento do trabalho cooperado, comunitário e coletivo dos produtores associados. E Marx vê somente esta última alternativa como passível de realização em uma sociedade com o significativo afastamento das barreiras naturais. No campo da produção, "a liberdade só pode consistir em que o homem social, os produtores associados, regulem racionalmente esse seu metabolismo com a Natureza, trazendo-o para seu controle comunitário, em vez de serem dominados por ele como se fora por uma força cega". (MARX, 1986 b, p. 273) Só assim, seria possível o cultivo racional, e não com o trabalho isolado; a questão, no que toca nosso tema é: 
isto é possível somente se a oposição entre cidade e campo vem a ser superada, tendo por base a preponderância do trabalho social - que aparece na figura do trabalhador coletivo - sobre o trabalho isolado. $O$ isolamento que o autor de $O$ capital critica no campo, portanto, não é um atributo inerente à indústria agrícola. Antes, ele vem da preponderância da pequena propriedade.

Esta preponderância, percebe-se, dentro do próprio capitalismo - até certo ponto - é quebrada. $\mathrm{O}$ trabalho social expande-se trazendo consigo a ruptura, insanável, no metabolismo social. Esta ruptura, tratada por Bellamy Foster (2005), traz uma cisão metabólica, cujas consequências no que toca o desperdício de recursos naturais é enorme. $\mathrm{O}$ trabalho social, em condições capitalistas de produção, expande-se na medida em que traz à tona uma oposição dramática entre cidade e campo. O meio pelo qual o trabalho social se torna preponderante não é, assim, a cidade, mas o processo subjacente ao desenvolvimento das categorias econômicas que estão por trás da oposição entre a vida rural e a urbana. E, neste ponto, diz Marx que a grande propriedade rural, ao mesmo tempo, traz o trabalho social do modo de produção capitalista ao campo e faz com que a contradição entre indústria rural e urbana se acentue. Percebe-se: o trabalho social, e a formação do trabalhador coletivo, trazem como potencialidade a formação da "propriedade dos produtores associados, como propriedade diretamente social" (MARX, 1986 a, p. 332), com a possibilidade da transição "do modo de produção capitalista ao modo associado". (MARX, 1986 a, p. 334) Ao mesmo tempo, tal possibilidade não se torna efetiva no modo de produção capitalista, precisando-se superar a forma de sociabilidade do capital para tanto. A aplicação da ciência no campo, bem como a grande propriedade rural são indícios de que o modo de produção capitalista está se tornando anacrônico; mas seria preciso um salto qualitativo para que o trabalho social possa se colocar com uma forma de propriedade diretamente social.

Para Marx, portanto, a pequena propriedade não é solução; antes, ela é parte do problema, já que representa o trabalho isolado no campo. Ao mesmo tempo, porém, a solução não está naquilo que é trazido em oposição a ela, a grande propriedade rural. Esta última pode até mesmo trazer potencialidades; mas expressa também a condição em que a população está, de um lado, amontoada em grandes centros urbanos e, doutro, tem-se a espoliação da terra, com a indústria rural. Se é verdade que, para o autor de $O$ capital, "o solo 'mais fértil' é sempre o 'mais fértil' nas condições dadas de produção" (MARX, 1980, p. 588), igualmente pode-se dizer que as condições capitalistas de produção trazem o desenvolvimento de forças produtivas como forças destrutivas. (Cf. SARTORI, 2018 c) Assim, diz Marx: "a produção capitalista só desenvolve a técnica e a combinação do processo de produção social na medida em que solapa os mananciais de toda a riqueza: a terra e o trabalhador." (MARX, 2013, p. 703) E, assim, desenvolve-se, sob o contraditório processo de expansão do trabalho social, a grande indústria e a grande agricultura: 
Se a pequena propriedade cria uma classe permanente de bárbaros meio à margem da sociedade, que conjuga toda a brutalidade de formas sociais primitivas com todas as torturas e toda a miséria de países civilizados, a grande propriedade soterra a força de trabalho na última região onde se refugia a sua energia natural e onde ela se armazena como fundo de reserva para a renovação da força vital das nações: na própria terra. Grande indústria e grande agricultura, exploradas industrialmente, atuam conjuntamente. Se, originariamente, elas se diferenciam pelo fato de que a primeira devasta e arruína mais a força de trabalho e por isso a força natural do homem e a última, mais diretamente a força natural da terra, mais tarde, ao longo do desenvolvimento, ambas se dão as mãos, ao passo que o sistema industrial na zona rural também extenua os trabalhadores e, por sua vez, a indústria e o comércio proporcionam à agricultura os meios para esgotamento da terra. (MARX, 1986 b, p. 266)

Marx trata da pequena propriedade de modo muito duro. Ela remeteria tanto ao trabalho isolado quanto a indivíduos que formariam uma classe de bárbaros. E mais; tais indivíduos se colocariam à margem da sociedade; a pequena propriedade traria consigo o pior dos mundos: a brutalidade de formas sociais primitivas e a miséria e torturas de países civilizados. No entanto, a resolução da questão, também sob este aspecto, não estaria na grande propriedade.

Esta última, inclusive, soterraria a força de trabalho e traria um elemento essencialmente espoliativo em relação à terra. No que há de se notar: se o enfoque de Marx, na década de 1840, está certamente nas cidades, o mesmo não se dá aqui do mesmo modo. A relação cidade-campo é tratada de modo mais equilibrado e a maneira pelo qual o autor passa pelas categorias da economia política (criticando-as), faz com que se tenha uma compreensão em que a grande indústria e a grande agricultura coloquem-se em um mesmo e só processo, o processo global de produção capitalista, tratado no livro III de $O$ capital, e essencial para a compreensão do modo de produção capitalista.

Interessante sobre este ponto ainda é destacar que não é só das cidades que poderia sair um movimento comunista. Isto se dá, não só em um nível de abstração maior, em que são assalariados tanto o trabalhador da indústria agrícola como o da indústria urbana. Tem-se isso também ao passo que as próprias formas sociais primitivas que se coloquem no campo e que não tenham passado pelo processo de consolidação da propriedade privada poderiam fornecer um ponto de partida para o socialismo. Este seria, por exemplo, o caso da Rússia, em que haveria tanto o "princípio da propriedade privada" (MARX; ENGELS, 2013, p. 96) quanto uma forma coletiva de apropriação da riqueza. Assim, diz Marx que seria possível que "eliminando o princípio da propriedade privada, igualmente implicado nela; ela pode tornar-se um ponto de partida direto do sistema econômico para o qual tende a sociedade moderna." (MARX; ENGELS, 2013, p. 96) A questão é essencial, e envolve a compreensão de meandros sobre os quais Marx se voltou nos últimos anos de sua vida. (Cf. MUSTO, 2018) Não se 
tem, assim, nem a cidade como um ponto de partida unívoco, nem a produção industrial como única forma passível de ser superada no socialismo.

Tem-se, de um lado, a cidade, a grande indústria e o lucro; doutro, o campo, o trabalho isolado e a renda. Mas, no desenvolvimento capitalista, a questão começa a se tornar complexa.

A atuação conjunta da grande indústria e da grande agricultura traz a exploração industrial tanto do campo quanto da cidade. A indissociabilidade e a mútua dependência do campo e da cidade ganham ainda mais contornos. Em um primeiro momento, a grande indústria urbana arruinaria a força de trabalho, ao passo que a grande indústria rural arruinaria a terra. Porém, com o desenrolar do processo em que ambas se situam, a questão se torna ainda pior: o comércio e a grande indústria atuam sobre a indústria rural exigindo o esgotamento espoliativo desta; o sistema industrial colocado na zona rural extenua os trabalhadores. Ou seja, no sistema capitalista de produção, de certo modo, tem-se certa superação, dentro do próprio capitalismo, da oposição entre cidade e campo: eles não estão mais colocados como separados, tem-se o trabalho social no campo, o isolamento e a pequena propriedade são, de certo modo, abolidos. Isto certamente fornece as bases para que, em uma forma de sociabilidade superior, fosse possível a real e efetiva supressão da oposição entre cidade e campo. Porém - e este ponto nos é essencial - no modo de produção capitalista, este processo é catastrófico: traz a irracionalidade da produção da grande indústria à zona rural e consegue extenuar tanto a terra quanto a força de trabalho. As forças produtivas desenvolvidas sobre o capitalismo começam a se colocar como destrutivas. Diz Marx sobre o assunto:"o modo de produção capitalista cai em nova contradição. Sua missão histórica é o desenvolvimento, inescrupuloso, impulsionado em progressão geométrica, da produtividade do trabalho humano." No que complementa: "ele se torna infiel a essa missão assim que, como aqui, se contrapõe ao desenvolvimento da produtividade, refreando-o. Com isso, só comprova novamente que se torna senil e que, cada vez mais, sobrevive a si mesmo." (MARX, 1986 a, p. 197) Tal forma de superação limitada e restrita da oposição entre cidade e campo é aquela de uma configuração de um capitalismo que já é anacrônico; torna-se senil, sobrevive a si mesmo, com o esgotamento da terra e com a exploração extenuante das forças produtivas do trabalho. Diz Marx em O capital:

Na esfera da agricultura, a grande indústria atua de modo mais revolucionário à medida que aniquila o baluarte da velha sociedade, o 'camponês', substituindoo pelo trabalhador assalariado. As necessidades de revolucionamento social e as antíteses do campo são, assim, niveladas às da cidade. No lugar da produção mais rotineira e irracional, surge a aplicação consciente, tecnológica da ciência. A ruptura do laço familiar original de agricultura e manufatura, que envolvia a configuração infantilmente não desenvolvida de ambas, é completada pelo modo de produção capitalista. Mas ele cria, ao mesmo tempo, os pressupostos materiais de uma síntese nova, mais elevada, da união entre agricultura e indústria com base em suas configurações antiteticamente elaboradas. Com a 
preponderância sempre crescente da população urbana que amontoa em grandes centros, a produção capitalista acumula, por um lado, a força motriz histórica da sociedade, mas perturba, por outro lado, o metabolismo entre homem e terra, isto é, o retorno dos componentes da terra consumidos pelo homem, sob forma de alimentos e vestuário, à terra, portanto, a eterna condição natural de fertilidade permanente do solo. Com isso, ela destrói simultaneamente a saúde física dos trabalhadores urbanos e a vida espiritual dos trabalhadores rurais. (MARX, 1996 b, p. 131-132)

Tal superação limitada da oposição entre cidade e campo traz consigo, com a grande indústria, a aniquilação do camponês, entendido aqui como o pequeno proprietário do campo. Ele seria, de certo modo, o baluarte da velha sociedade. A atuação da grande indústria, assim, seria revolucionária. Ao mesmo tempo, não resolutiva: ela traria a grande propriedade agrária.

E neste ponto tem-se algo importante: no que toca o ponto central das contradições da sociedade capitalista, as necessidades de revolucionamento social no campo e na cidade estariam niveladas. Uma vez que o trabalhador rural se torna também um assalariado, os antagonismos do campo e da cidade, em sua essência, são os mesmos; e isto se dá até mesmo porque separar o desenvolvimento da zona rural daquela da zona urbana vem a se tornar ainda mais inviável.

Tanto no campo quanto na cidade, começa a surgir a ciência como uma força produtiva, o que traz enormes possibilidades (embora estas não sejam efetivas) no que diz respeito ao incremento das forças produtivas; o liame original (limitado) entre agricultura e a manufatura também vem a ser rompido, podendo-se ultrapassar os limites, que Marx diz ser de uma configuração infantil, de ambas. Tem-se, assim, na grande indústria, com as grandes possibilidades emergentes os pressupostos materiais para a superação do próprio capitalismo. No que, neste ponto, devemos destacar: não é tanto a cidade e a vida urbana que se colocam com potencialidades que vão além do modo de produção capitalista. Antes, o processo social que engendra a oposição entre cidade e campo é o mesmo que a torna socialmente supérflua. $E$ isto se dá porque tem-se a possibilidade de uma síntese superior, uma síntese nova, que se colocaria na união entre agricultura e indústria. No que diz respeito ao tema que aqui tratamos, tem-se, com esta síntese nova, o solo sobre o qual pode se dar a supressão da oposição entre cidade e campo. Se formos levar a sério a crítica da economia política que desenvolve Marx, deve-se dizer: sem tratar desde desenvolvimento, os posicionamentos sobre o urbano e o rural ficam vazios, pairam no ar.

Os centros urbanos, em meio a este processo, e somente podendo ser compreendidos neste contexto, são o locus das grandes populações e, com isto, trazem consigo a força motriz histórica da sociedade. Ao mesmo tempo, tem-se a ruptura metabólica, que deteriora a ligação entre o homem e a natureza no que toca o consumo, a produção e o retorno dos componentes à terra. Este metabolismo 
entre homem e terra só poderia ser recuperado em uma síntese superior em nova entre agricultura e indústria, e entre cidade e campo, o urbano e o rural. No modo de produção capitalista, a saúde dos trabalhadores urbanos (e, depois de certo ponto, também a dos rurais) é destruída ao passo que a vida espiritual dos trabalhadores rurais (e, com a evolução da relação-capital, dos urbanos) é igualmente vilipendiada. Vê-se, portanto, que: 1) a pequena propriedade no campo não só não é solução para Marx. Ela representa o elemento reacionário do camponês; 2) a grande propriedade agrária significa o entrelaçamento entre a grande indústria e a indústria agrícola; 3) tal entrelaçamento, ao mesmo tempo, traz o incremento das forças produtivas e a destruição destas; 4) a implementação da vida urbana no campo, com suas contradições, não é resolutiva. Antes, o avanço do trabalho social ao campo significa, no campo econômico, o nivelamento dos problemas que se colocam na cidade e no campo; 5) tratar-se-ia, portanto, da necessidade da supressão da oposição entre cidade e campo e, portanto, do desenvolvimento de uma síntese superior entre a grande indústria e a produção agrícola; 6) isto só seria possível com a apropriação coletiva da terra e dos meios de produção, correlacionada à produção de trabalhadores livremente associados.

\section{A PROPRIEDADE ESTATAL DA TERRA TRAZ SOCIALISMO?}

O modo pelo qual o processo que tratamos acima se coloca traz como consequência também a aplicação da ciência no campo. Como já dissemos, tal não conforma real e efetivamente a supressão da oposição entre cidade e campo; antes de tratar de tal aspecto, porém, é preciso que se diga que, caso a apropriação da renda fosse estatal, não se teria uma resolução da questão também. É importante destacar este aspecto agora para que não se tenha mal-entendidos sobre o assunto, que podem ser análogos àqueles que se dão ao tratar da suposta supressão efetiva da oposição entre cidade e campo que se tem com grande indústria trazendo o trabalho social ao campo. Veja-se:

Se o Estado se apropriasse da terra e prosseguisse a produção capitalista, a renda II, II, IV seria paga ao Estado, a própria renda continuaria a existir. Se a terra se tornasse propriedade do povo, desapareceria em geral a base da produção capitalista, o fundamento sobre o qual se a apoia a autonomiza, em face do trabalhador, das condições de trabalho. (MARX, 1980, p. 532)

Para Marx, a solução não está na apropriação estatal da renda na zona rural ou do lucro na indústria urbana ${ }^{11}$, mas na supressão destas categorias. $O$ encadeamento delas seria

\footnotetext{
${ }^{11}$ Para uma análise sobre o assunto nas sociedades pós-capitalistas, Cf. MÉSZÁROS, 2002.
} 
típico do modo de produção capitalista (embora elas tenham existido, com menor relação entre si, em outros modos de produção); e, assim, trata-se, para o autor, da supressão do próprio sistema capitalista de produção. Isto supõe que a propriedade da terra seja do povo e que a produção seja associada. ${ }^{12}$

Ou seja, trata-se de uma situação em que as condições de trabalho não se opõem como uma força, como uma potência estranha aos indivíduos. Como já destacamos, no campo da produção, que sempre continua sendo mediado pela necessidade material, "a liberdade só pode consistir em que o homem social, os produtores associados, regulem racionalmente esse seu metabolismo com a Natureza, trazendo-o para seu controle comunitário", no que continua Marx "em vez de serem dominados por ele como se fora por uma força cega." (MARX, 1986 b, p. 273) ${ }^{13}$ Assim, mesmo que o Estado aplicasse a ciência no campo, e mesmo que a grande propriedade rural se tornasse estatal, não se teria aquilo que Marx chamou de modo de produção associado. 0 máximo que se chegaria seria a figuras de transição - sempre de desenvolvimento dramático - que se colocam em meio ao próprio funcionamento do modo de produção capitalista. (Cf. SARTORI, 2019 b, a) Tal qual as sociedades por ações e as cooperativas - tratadas por Marx no livro III de O capital - não superam o modo de produção capitalista real e efetivamente (Cf. SARTORI, 2019 b), tem-se que a propriedade estatal das terras não poderia dar ensejo a isto. (Cf. MÉSZÁROS, 2002, 2007)

Em verdade, até mesmo do ponto de vista capitalista, o proprietário da terra não é um elemento essencial. Com o processo em que se ligam grande indústria e a indústria agrária, para o empresário da grande indústria, até certo ponto, o indivíduo que vive da renda da terra é um

\footnotetext{
${ }^{12}$ Isto se dá mesmo que, para Marx, "o proprietário da terra desempenha, no entanto, um papel no processo de produção capitalista não só pela pressão que ele exerce sobre o capital, nem só porque a grande propriedade fundiária é um pressuposto e uma condição da produção capitalista - visto que constitui a expropriação das condições de trabalho do trabalhador -, mas especialmente porque ele aparece como personificação de uma das condições essenciais da produção." (MARX, 1986 b, p. 274)

${ }^{13}$ Veja-se a passagem completa de Marx: "a riqueza real da sociedade e a possibilidade de constante expansão de seu processo de produção não depende, portanto, da duração do mais-trabalho, mas de sua produtividade e das condições mais ou menos ricas de produção em que ela transcorre. O reino da liberdade só começa, de fato, onde cessa o trabalho determinado pela necessidade e pela adequação a finalidades externas; portanto, pela própria natureza da questão, isso transcende a esfera da produção material propriamente dita. Assim como o selvagem tem de lutar com a Natureza para satisfazer suas necessidades, para manter e reproduzir sua vida, assim também o civilizado tem de fazê-lo, e tem de fazê-lo em todas as formas de sociedade e sob todos os modos de produção possíveis. Com seu desenvolvimento, amplia-se esse reino da necessidade natural, pois se ampliam as necessidades; mas, ao mesmo tempo, ampliam-se as forças produtivas, que as satisfazem. Nesse terreno, a liberdade só pode consistir em que o homem social, os produtores associados, regulem racionalmente esse seu metabolismo com a Natureza, trazendo-o para seu controle comunitário, em vez de serem dominados por ele como se fora por uma força cega; que o façam com o mínimo emprego de forças e sob as condições mais dignas e adequadas à sua natureza humana. Mas este sempre continua a ser um reino da necessidade. Além dele é que começa o desenvolvimento das forças humanas, considerado como um fim em si mesmo, o verdadeiro reino da liberdade, mas que só pode florescer sobre aquele reino da necessidade como sua base. A redução da jornada de trabalho é a condição fundamental." (MARX, 1986 b, p. 273)
} 
obstáculo; trata-se de alguém com quem partilhar a distribuição do mais-valor. (Cf. SARTORI, 2019 b) Ou seja, dentro do modo de produção capitalista não é possível a propriedade coletiva, do povo, no que toca a terra. Mas há posições burguesas mais radicais que a defesa do dono da terra:

Suposto o modo de produção capitalista, o capitalista não é só funcionário imprescindível da produção, mas o funcionário predominante. 0 dono da terra, ao revés, é de todo supérfluo no modo capitalista de produção. Este modo de produção precisa apenas que a terra não seja propriedade comum, se oponha à classe trabalhadora como condição de produção que não pertence a essa classe, e se atinge por completo esse objetivo quando a terra se torna propriedade do Estado, isto é, o Estado percebe a renda fundiária. O dono da terra, funcionário tão essencial da produção no mundo antigo e no medieval é na era industrial inútil, excrescência. O burguês radical (cobiçando também a supressão de todos os outros tributos) avança no plano teórico para negar a propriedade privada da terra, que desejaria tornar propriedade comum da classe burguesa, do capital, na forma de propriedade do Estado. Na prática, entretanto, falta coragem, pois o ataque a uma forma de propriedade uma forma de propriedade privada das condições de trabalho - seria muito perigoso para a outra forma. Ademais, o próprio burguês tornou-se dono de terras. (MARX, 1980, p. 477)

O dono da terra poderia ser substituído, ao passo que o capitalista, real e efetivamente, não. ${ }^{14}$ Marx chega mesmo a dizer que o dono da terra é supérfluo ao modo de produção capitalista. A propriedade da terra não poderia ser comum, não poderia ser do povo. Mas seria possível outra forma de apropriação desta que não a propriedade privada individual. Se é necessário que as condições de trabalho, neste caso da terra, oponham-se ao trabalhador como uma força estranha, isto não necessariamente precisaria se dar com a centralidade do dono da terra. $O$ próprio Estado poderia se apropriar da parcela do mais-valor que aparece ${ }^{15}$ na renda fundiária.

Como dissemos, porém, esta continuaria sendo renda fundiária. O que muda é: o capitalista é um funcionário essencial ao passo que o dono da terra, não. Se ele o era na produção antiga e medieval, o mesmo não se dá mais. Ou seja, podemos compreender como que a cidade domina o campo na sociedade capitalista tendo isto em conta. $O$ processo pelo qual se instaura a subordinação do campo à cidade é aquele em que o capitalista se torna um funcionário essencial, e o dono de terras uma excrecência. O movimento em que a propriedade estatal da terra é cogitada é aquele em que, como já mencionado, "a grande indústria e a grande propriedade, exploradas industrialmente, atuam conjuntamente." (MARX, 1986 b, p. 266) Assim, no limite, uma posição que procurasse a apropriação estatal da renda da terra não seria propriamente a de Marx, mas aquela do burguês radical. Este último, ao defender a propriedade estatal da terra, contra a propriedade privada, vem a trazer à tona

\footnotetext{
${ }^{14}$ Isto se dá mesmo com figuras da produção capitalista como as fábricas cooperativas, do trabalho remunerado de supervisão e das sociedades por ações, tratadas por Marx no livro III de O capital. (Cf. SARTORI, 2019 b)

${ }^{15}$ Sobre as formas de aparição e de representação na sociedade capitalista, Cf. GRESPAN, 2019.
} 
a oposição entre os interesses dos indivíduos burgueses e os interesses da classe burguesa como tal, representados no Estado. O capital, na forma de propriedade do Estado, traz consigo a propriedade comum da classe burguesa, e não a propriedade comunal ou do povo.

Nota-se, porém, que existem meandros na questão: Marx diz que falta coragem à burguesia para colocar tal posição em ação. Uma primeira razão para isto diz respeito ao ataque a uma forma de propriedade privada; segundo Marx, isto poderia, até certo ponto, representar - mesmo que não seja efetivamente - um perigo para a propriedade privada como tal. E, assim, mesmo que a renda da terra e a posição do dono de terras seja irrracional, mesmo do ponto de vista capitalista, seria melhor à burguesia se ater a esta figura do desenvolvimento capitalista que abrir espaço à crítica ao modo de produção capitalista como tal. No entanto, a segunda razão talvez seja mais importante no que diz respeito ao tema tratado neste artigo: para que não se tenha como regra a propriedade estatal da terra no sistema capitalista de produção, o próprio burguês começa a se tornar proprietário de terras. Ou seja, tal qual se dá com o capital portador de juros e com o capital comercial, a produção propriamente capitalista começa a se apropriar de formas antediluvianas de capital e a as trazer para o centro do modo de produção capitalista. Isto tem dois aspectos que podemos levantar aqui: um deles aparece ao passo que isto leva a se trazer o funcionamento industrial ao campo. Ou seja, o funcionamento da produção no campo passa a trazer, em essência, os mesmos problemas da produção da indústria urbana. A expansão da grande indústria e do trabalho social transformam o camponês, de pequeno proprietário em assalariado. E, assim, o elemento preponderante nas contradições sociais que marcam o campo passa a ser o antagonismo entre trabalho e capital. O segundo elemento diz respeito ao modo como se passa a ter as condições materiais para que se traga uma forma superior de unidade entre produção industrial e agrícola com a supressão da oposição entre cidade e campo. Ambas as razões apontadas ligam-se ao processo em que a oposição entre vida urbana e rural tornase anacrônica; ela é, até certo ponto, superada. Mas não o é efetivamente. Abre-se, assim, mais espaço para a supressão da oposição cidade-campo. Este espaço é trazido à tona pelo próprio desenvolvimento contraditório das categorias econômicas, que se apresentam no modo de produção capitalista e que são tratadas na economia politica. Sem a análise desta, não é possível passar por temas ligados à cidade, ao campo e às relações contraditórias entre estas.

No caso, em Marx, a crítica a tal situação se dá com a própria crítica da economia política, sem a qual não se pode tratar de nosso tema. E, assim, pode-se notar: mesmo que a propriedade estatal das terras do campo não possa ser regra na vigência plena do modo de produção capitalista ${ }^{16}$, ela não

\footnotetext{
${ }^{16}$ A questão desta vigência plena é bastante meandrada. Sobre o assunto, Cf. MÉSZÁROS, 2002.
} 
seria resolutiva das questões sociais que se impõem aos indivíduos diuturnamente; tal forma de propriedade, se formos ter em conta os posicionamentos de Marx, não seria sequer socialista.

\section{DESENVOLVIMENTO DA CIÊNCIA, AGRONOMIA E O DESENVOLVIMENTO DAS RELAÇÕES DE PRODUÇÃO NO CAMPO: A POSSIBILIDADE DA COMUNA AGRÁRIA COMO PONTO DE PARTIDA}

A relação entre cidade e campo passa por elementos naturais, certamente. No entanto, tais aspectos, ligados a determinações dos solos, do relevo, etc. estão relacionados por mediações sociais. Neste sentido, o desenvolvimento científico e a conformação da ciência como uma força produtiva traz alterações no próprio modo pelo qual interagem o espaço urbano e o rural. Diz Marx:

Com o desenvolvimento das ciências naturais e da agronomia também se modifica a fertilidade do solo à medida que se modificam os meios pelos quais os elementos do solo podem vir a ser imediatamente utilizados. Foi assim que, há pouco tempo, tipos leves de solo na França e nos condados orientais da Inglaterra, antes considerados ruins, se elevaram ao primeiro nível. Por outro lado, solos considerados ruins não por sua composição química, mas porque opunham certos obstáculos físico-mecânicos ao cultivo, se transformam em terra boa assim que se descobrem os meios para superar tais obstáculos. (MARX, 1986 b, p. 233)

A fertilidade do solo não é, portanto, um dado bruto. Antes, conforma-se em meio a determinada disposição de meios sociais de produção - e, portanto, de formas de apropriação da natureza. A utilização do solo é sempre mediada por determinado modo de produção. Trata-se do processo de afastamento das barreiras naturais. (Cf. LUKÁCS, 2013) Assim, tem-se, com a aplicação da ciência, no caso das ciências naturais e da agronomia, uma mudança substancial na relação dos homens com a natureza. $\mathrm{E}$ isto faz com que a relação entre o elemento rural e o urbano não condiga mais a uma oposição entre a idiotia rural e a cultura dos grandes centros urbanos.

Um dos grandes resultados do modo de produção capitalista é que, por um lado, transforma a agricultura, de um procedimento meramente empírico e mecânico tradicional da parte menos desenvolvida da sociedade num emprego científico consciente da Agronomia, desde que isso seja possível sob as condições da propriedade privada; dissocia inteiramente a propriedade fundiária das relações de dominação e servilismo feudais, e ainda separa por completo o solo, enquanto condição de trabalho, da propriedade fundiária e do senhor da terra, para o qual a terra representa apenas um tributo em dinheiro que, por meio de seu monopólio, ele arrecada do capitalista industrial, o arrendatário. (MARX, 1986 b, p. 125) 
A produção capitalista traz também a superação de um modo de produzir baseado em elementos simplesmente empíricos. A chegada do trabalho social ao campo traz também a mediação da ciência, de modo que - mesmo que com limitações - permite o emprego científico consciente da agronomia. Tal emprego não é mais compatível com a pequena propriedade camponesa, tendo-se a grande propriedade, que acompanha o desenvolvimento da grande indústria. Deste modo, as limitações da aplicação da ciência não estão mais ligadas tanto à ausência de desenvolvimento desta, ou à distância entre cidade e campo. Em verdade, o maior entrave passa a ser a propriedade privada. E, assim, a barreira ao incremento da produção está colocada no próprio sistema capitalista.

Sobre tal aspecto, diz Marx que:

Do ponto de vista de uma formação econômica superior da sociedade, a propriedade privada de certos indivíduos sobre o globo terrestre parecerá tão absurda quanto a propriedade privada de um ser humano sobre outro ser humano. Mesmo uma sociedade inteira, uma nação, mesmo todas as sociedades coevas em conjunto não são proprietárias da Terra. São apenas possuidoras, usufrutuárias dela, e como 'boni paters familias' devem legá-la melhorada às gerações posteriores. (MARX, 1986 b, p. 239)

Marx ataca como irracional a própria propriedade da terra. Pode-se apropriar da riqueza da terra e do trabalho; mas seria absurdo a uma forma de sociabilidade superior tratar da terra e do trabalho como algo alienável. Tais mananciais de riqueza poderiam ser usufruídos; a terra poderia ser possuída, mas sempre deveria ser legada às gerações posteriores. Uma atitude agressiva e espoliativa diante da terra e do trabalho seria típica do modo de produção capitalista, sendo preciso superar tal forma de produção social. No que se deve destacar que, para o autor de $O$ capital, a partir do momento em que se tem a possibilidade de o campo não se colocar em meio a certa idiotia rural, pode-se mesmo cogitar revoluções sociais cujo início não estaria nas cidades.

A questão é importante para o nosso tema e significa que a superação real da oposição entre cidade e campo poderia partir de um elemento rural, a depender das circunstâncias. Sempre tais questões dizem respeito às peculiaridades das formações sociais analisadas. $E$, no que diz respeito ao tema deste artigo, deve-se ver a posição de Marx quanto à Rússia:

Uma circunstância muito favorável do ponto de vista histórico à conservação da "comuna agrícola" pela via do seu desenvolvimento ulterior consiste em que ela não só é contemporânea da produção capitalista ocidental - podendo assim se apropriar dos frutos sem se sujeitar ao seu modus operandi -, mas também sobreviveu à época em que o sistema capitalista se apresentou ainda intacto, em que ela o encontra, pelo contrário, na Europa ocidental, assim como nos Estados Unidos, em luta contra as massas trabalhadoras, contra a ciência, contra as próprias forças produtivas que engendra - em suma, ela o encontra numa crise que terminará com a sua eliminação, com o retorno das sociedades modernas a 
uma forma superior de um tipo "arcaico" da propriedade e da produção coletivas. (MARX, ENGELS, 2013, p. 95-96)

Haveria uma luta do próprio capitalismo contra a ciência, ao passo que a aplicação desta ao campo seria uma realidade. O modo pelo qual Marx trata da comuna agrícola russa é muito interessante para nosso tema: com o incremento da produção em escala mundial, tal comuna não está simplesmente isolada; ela é agrícola, mas pode usufruir da ciência já que é contemporânea da produção capitalista ocidental; ela não passou pelo processo de privatização das terras, tendo-se como elemento essencial na produção agrícola, não a pequena propriedade privada ou a grande propriedade, mas a propriedade coletiva; por fim, trata-se de uma forma social arcaica, mas que pode fornecer um ponto de partida para a propriedade e produção coletivas.

Tais características nos são essenciais porque mostram que, com a aplicação das ciências naturais e da agronomia no campo, seria possível uma mudança substantiva na indústria agrícola. Tal mudança teria como principal freio a propriedade privada. Esta última, porém, não seria prioritária na comuna agrária russa e, deste modo e naquele momento, seria possível uma passagem direta desta forma social ao socialismo. Seria preciso mudanças no campo da produção: "ela pode substituir gradualmente a agricultura parceleira pela agricultura extensiva com o auxílio de máquinas, a que convida a configuração física da terra russa." E, com isso, continua Marx: "ela pode, portanto, tornarse o ponto de partida direto do sistema econômico para o qual tende a sociedade moderna e trocar de pele sem ter de cometer suicídio." (MARX, ENGELS, 2013, p. 101) No que se nota que uma revolução russa teria, também, uma base agrária; e isto ocorreria, à época de Marx, ao passo que a aplicação da ciência estaria ao lado dos socialistas, e não mais do capitalismo. O sistema capitalista de produção se colocaria, então, contra a ciência.

Marx, assim, enfatiza as conquistas positivas do capitalismo, mas destaca que o processo pelo qual tais conquistas se deram - que passa pela acumulação originária, pelo colonialismo, etc. - não precisaria se repetir em todos os países. O desenvolvimento desigual das formações sociais faz com que a especificidade destas últimas deva ser considerada ao se ter em conta, ao mesmo tempo, o funcionamento da totalidade do modo de produção. ${ }^{17}$ Ou seja, tem-se como um elemento importante a relação cidade-campo, mas também tem-se que esta se insere no mercado mundial.

\footnotetext{
${ }^{17}$ Marx traz à tona algo que não poderemos analisar, mas que merece ser destacado: "em países de produção capitalista têm participação indireta na produção agrícola muitas pessoas ·que nela se integram nos países menos desenvolvidos. A diferença, porém, parece maior do que é. Mas essa diferença é muito importante para o conjunto da civilização do país, mesmo quando consista apenas em que grande parte dos produtores empenhados na agricultura não tenha participação direta nela, tenha sido arrancada do idiotismo da vida rural e pertença à população industrial." (MARX, 1980, p. 913)
} 
No que diz Marx sobre a comuna agrícola russa:

De um lado, a propriedade comum da terra lhe permite transformar de modo direto e gradual a agricultura parceleira e individualista em agricultura coletiva, sendo que os camponeses russos já a praticam em pradarias indivisas; a configuração física do seu solo convida à exploração mecânica em larga escala; a familiaridade do camponês com o contrato de artel facilita a transição do trabalho parceleiro para o trabalho cooperativo e, por fim, a sociedade russa, que há tanto tempo vive às custas deles, deve-lhes os adiantamentos necessários para essa transição. De outro lado, a contemporaneidade da produção ocidental, que domina o mercado mundial, permite à Rússia incorporar à comuna todas as conquistas positivas produzidas pelo sistema capitalista sem passar por seus forcados caudinos. (MARX, ENGELS, 2013, p. 94)

Destaca-se a propriedade comum da terra; ela é tanto algo que impossibilita o capitalismo quanto algo que traz a possibilidade da passagem de uma forma de apropriação coletiva a outra, superior. As conquistas positivas do capitalismo, principalmente por meio da ciência e da cooperação, poderiam ser incorporadas sem que a Rússia precisasse passar necessariamente por um processo de acumulação originária capitalista. 0 ponto de partida para uma transição socialista, assim, não estaria na cidade, como acreditava Marx em A ideologia alemã. No caso russo, ter-se-ia o oposto. Deve-se destacar, porém, que isto não se dá de modo "romântico" ou com base nos atributos idílicos do campo. O autor de $O$ capital é muito enfático quanto à questão. Tal caráter idílico do campo se liga à idiotia rural, relacionada à pequena propriedade agrária. Esta última não seria a base da produção russa, embora, de certo modo, fosse também uma possibilidade.

Falando em termos teóricos, a "comuna rural" russa pode, portanto, conservarse, desenvolvendo sua base, a propriedade comum da terra, e eliminando o princípio da propriedade privada, igualmente implicado nela; ela pode tornar-se um ponto de partida direto do sistema econômico para o qual tende a sociedade moderna; ela pode trocar de pele sem precisar se suicidar; ela pode se apropriar dos frutos com que a produção capitalista enriqueceu a humanidade sem passar pelo regime capitalista, regime que, considerado exclusivamente do ponto de vista de sua duração possível, conta muito pouco na vida da sociedade. Porém, é preciso descer da teoria pura à realidade russa. (MARX, ENGELS, 2013, p. 96)

Haveria certa tensão entre o princípio da propriedade privada e a propriedade comum da terra. Isto apareceria na comuna rural, que, para poder oferecer um ponto de partida ao socialismo, precisaria ser preservada e regenerada. Para que fosse possível a supressão do modo de produção capitalista e, com ele, da oposição entre cidade e campo, seria preciso, em um primeiro momento, regenerar uma forma arcaica de produção. Isto se daria na medida em que a comuna poderia fornecer o elo entre uma forma coletiva e arcaica de apropriação social a uma forma moderna de produção coletiva. Tudo isso, claro, só seria possível descendo à realidade russa. 
Para o que nos diz respeito aqui, fica claro que, mesmo quando Marx trata da necessidade de regenerar uma forma produtiva arcaica, ele não está a elogiar qualquer elemento idílico. Antes, tem em conta possibilidades concretas e ligadas à possibilidade da superação do modo capitalista de produção. Isto só seria possível com o afastamento das barreiras naturais e com o controle consciente das condições de vida; a aplicação da ciência e da maquinaria no campo seria fundamental; Marx, porém, não elogia prometeicamente a cidade, nem é um romântico e nostálgico quanto à vida rural. Tais posições unilaterais são igualmente criticadas pelo autor.

\section{CONSIDERAÇÕES FINAIS}

Pelo que vimos, há um tratamento bastante interessante sobre a relação entre cidade e campo na obra de Karl Marx. Ao mesmo tempo em que, claro, este tratamento não é suficiente para a fornecer "a" base para a resolução da questão, ele ilumina diversos pontos, que já estavam presentes na obra do autor de $O$ capital. Ou seja, ao tratar da anatomia do modo de produção capitalista, passa-se por diversos pontos que são analisados, também, por autores contemporâneos.

Sendo que tais autores, de um modo ou doutro, sempre posicionam-se diante de Marx, é bom que se tenha analisado certos meandros da teoria marxiana.

Vimos, assim, que o autor alemão não é simplesmente um entusiasta acrítico da grande indústria e dos centros urbanos; ao mesmo tempo, não é também alguém que vê no campo um ambiente ontologicamente conservador e reacionário. Os meandros da questão são muitos, e procuramos tê-los trazido acima. Restou claro que, no autor, não se trata de conservar o urbano contra o rural, e nem do oposto; antes, tem-se a necessidade de, com a supressão do sistema capitalista de produção, superar a oposição cidade-campo; teve-se também que o sujeito deste processo são os próprios homens, em relações sociais de produção determinadas; vimos que a oposição cidade-campo só poderia ser suprimida devido ao desenvolvimento que se dá no seio do próprio modo de produção capitalista, mesmo que se tenha a necessidade de abolir este último; com a grande indústria, chega a ciência e o trabalho social ao campo, tendencialmente, superando a pequena propriedade e a idiotia rural, de modo que a oposição entre cidade e campo é trazida à tona sob as bases da própria oposição entre trabalho e capital; por fim, não seria só a cidade o ponto de partida de um movimento comunista. Em circunstâncias específicas, diante do que dissemos, seria possível, como teria acontecido na Rússia, que uma revolução social partisse do campo. 
Com a análise de tais pontos, e do raciocínio do autor, tratado acima, nota-se que o pensamento marxiano é bastante diferente de certas caricaturas que são difundidas sobre ele. No que toca a relação cidade-campo, isto é bastante claro.

\section{REFERÊNCIAS:}

BARAN, Paul. Economia política do desenvolvimento. Trad. S. Ferreira da Cunha. São Paulo: Zahar, 1960.

BELLAMY FOSTER, Jonh. A ecologia de Marx. Trad. Maria Teresa Machado. Rio de Janeiro: Civilização Brasileira, 2005.

CANDIDO, Antonio. Parceiros do Rio Bonito. São Paulo: Edusp, 2017.

CHASIN, José. Ensaios Ad Hominem, Tomo III - Política. São Paulo: Ensaio, 1999.

Marx: Estatuto Ontológico e Resolução Metodológica. São Paulo: Boitempo, 2009.

COTRIM, Vera. Trabalho produtivo em Karl Marx: novas e velhas questões. São Paulo: Alameda, 2013.

DAVIS, Mike. Planeta favela. Trad. Beatriz Medina. São Paulo: Boitempo, 2006.

DOBB, Maurice. A evolução do capitalismo. Trad. Manoel de Rego Braga. São Paulo: Abril Cultural, 1983.

ENGELS, Friedrich. Anti-Dühring. Rio de Janeiro: Paz e Terra, 1990.

Esboço de uma crítica à economia política. Tradução por Maria Filomena Vieras. In:

Revista Temas de Ciências Humanas. São Paulo: Livr. Ed. Ciências Humanas, 5, 1979.

Questão da habitação. São Paulo, Editora Acadêmica, 1988.

2010.

Situação da classe trabalhadora na Inglaterra. Trad. B.A Schumann. São Paulo: Boitempo,

Origem da família, da propriedade privada e do Estado. Trad. Ruth M. Klauss. São Paulo: Centauro, 2002.

GRESPAN, Jorge. Marx e a crítica ao modo de representação capitalista. São Paulo: Boitempo, 2019. HARVEY, David. A produção capitalista do espaço. Trad. Carlos Szlak. São Paulo: Annablume, 2005. LEFEBVRE, Georges. As origens da revolução francesa. Trad. Cláudia Berliner. Rio de Janeiro: Paz e terra, 1989. 
LEFEBVRE, Henri. A cidade do capital. Trad. Maria Helena Rauta Ramos e Marilena Jamur. Rio de Janeiro: DP\&A, 2001.

Posição: contra os tecnocratas. Trad. T.C Netto. São Paulo: Nova crítica, 1969

LUKÁCS, György. Para uma ontologia do ser social II. Trad. Nélio Schneider. São Paulo: Boitempo, 2013.

MARX, Karl. Contribuição à Crítica da Economia Política. Trad. Florestan Fernandes. São Paulo: Expressão Popular, 2009.

Crítica à filosofia do Direito de Hegel. Trad. Rubens Enderle e Leonardo de Deus. São Paulo: Boitempo, 2005.

Grundrisse. Trad. Mario Duayer. São Paulo: Boitempo, 2011.

Glosas marginais ao Manual de economia política de Adolph Wagner. Trad. Luiz Philipe De Caux. In: Verinotio: revista on-line de filosofia e ciências humanas, V. 23, N. 2. Rio das Ostras: UFF, 2017

Manuscritos econômico-filosóficos. Trad. Rubens Enderle. São Paulo: Boitempo, 2010.

O Capital, Livro I. Trad. Rubens Enderle. São Paulo: Boitempo, 2013

O Capital, livro III, tomo I. Trad. Tradução por Regis Barbosa e Flávio R. Kothe São Paulo: Nova Cultural, 1986 a.

. O Capital, livro III, tomo II. Trad. Tradução por Regis Barbosa e Flávio R. Kothe São Paulo: Nova Cultural, 1986 b.

Teorias da mais-valia. Trad. Reginaldo Sant'Anna. São Paulo: Civilização brasileira, 1980.

MARX, Karl; ENGELS, Friedrich. Ideologia alemã. Trad. Rubens Enderle. São Paulo: Boitempo, 2007.

O Manifesto Comunista. Trad. Maria Lucia Como. Rio de Janeiro: Paz e Terra, 1998.

MÉSZÁROS, István. O desafio e o fardo histórico de nosso tempo. Trad. Ana e Vera Cotrim. São Paulo: Boitempo, 2007.

2002.

Para além do capital. Trad. Paulo Cezar Castanheda e Sérgio Lessa. São Paulo: Boitempo,

MUSTO, Marcelo. O velho Marx. Trad. Rubens Enderle. São Paulo: Boitempo, 2018.

PARREIRA, Lucas. Entre flexas e martelos: Marx como leitor de Henry Morgan (dissertação de mestrado). Belo Horizonte: UFMG, 2019.

SARTORI, Vitor Bartoletti. Acerca da individualidade, do desenvolvimento das forças produtivas e do romantismo em Marx. In: Lutas comunais, n. 1, v. 1. Belo Horizonte: UFMG, 2018 c. 
Direito, política e reconhecimento: apontamentos sobre Karl Marx e a crítica ao Direito. Revista da Faculdade de Direito da UFPR, V. 61. Curitiba: UFPR, 2016.

Fetichismo, transações jurídicas, socialismo vulgar e capital portador de juros: o livro III de $\mathrm{O}$ capital diante do papel ativo do Direito. Revista da Sociedade Brasileira de Economia política. Niterói: UFF, 2019 a.

. Sociedades capitalistas tardias, o livro III de $\mathrm{O}$ capital e a dialética entre trabalho e as figuras econômicas concretas. In: Revista de estudos organizacionais, V. 6, N.1. Rio de Janeiro: UFF, 2019 b.

WILLIAMS, Raymond. Cidade e campo. Trad. Paulo Henriques Brito. São Paulo: Companhia das letras, 2011.

WOOD, Ellen. Origens do capitalismo. Trad. Vera Ribeiro. São Paulo: Zahar, 2001.

Trabalho recebido em 16 de setembro de 2019

Aceito em 15 de março de 2021 